\author{
JANUSZ ŁACH \\ ORCID https://orcid.org/0000-0001-8451-5957 \\ Uniwersytet Wrocławski \\ IGOR BOJKO \\ ORCID https://orcid.org/0000-0002-3828-1835 \\ Ukraińska Akademia Nauk we Lwowie
}

\title{
POLANIARSTWO JAKO ISTOTNY WYRÓŻNIK W BADANIACH NAD TYPOLOGIĄ KRAJOBRAZÓW PASTERSKICH KARPAT ZACHODNICH
}

\author{
Agro-shepherd as a Significant Landmark in the Research \\ on Typology of Pastoral Landscapes in the Western Carpathians
}

WYRAZY KLUCZOwE: Karpaty Zachodnie, Beskid Mały, pasterstwo, polaniarstwo, kultura wo-
łoska, wyróżniki i wyznaczniki krajobrazowe

KeYwORDs: Western Carpathians, Little Beskids, pastoralism, agro-shepherd economy, Wallachian culture, landmark and determinants of landscape

Aвstract: The article is an attempt to use the method of landmark and determinants in research on the typology of pastoral and agricultural landscapes in the area of the Beskids range the Western Carpathians. The paper analyzes the structure and form of economic activities in the mid-forest clearing, allowing to define mountain landscapes. The Beskids landscape due to the varied morphology, terrain cover and the Vlachs cultural element is considered to be particularly valuable in terms of landscape. The definition of the natural and cultural aspects of the Beskids landscapes made it possible to separate, in the type of rural landscapes - the pastoral subtype, the pastoral and agricultural landscape called as the agro-shepherd.

\section{Wstęp}

Krajobrazy pasterskie w Polsce zostały przez U. Mygę-Piątek (2012) określone jako „reliktowe”. Nieliczne wypasy górskie w Tatrach, na Podhalu, w Beskidzie Śląskim, Żywieckim czy Gorcach mają już tylko postać wypasu kulturowego, a nie głównych form gospodarki regionu. Powszechnie można się z tą tezą zgodzić, odnosząc się do pasterstwa szałaśniczego - wędrownego, jednakże zarówno na obszarze Beskidów Polskich, jak i Ukraińskich krajobraz nadal kształtują działania pastersko-rolne, wpływając na mozaikową strukturę złożoną z płatów leśnych, polan oraz duktów śródleśnych. Te wyjątkowe dla regionu karpackiego krajobrazy nie zostały jak 
dotąd objęte typologią (Chmielewski i in. 2015). Istnieje więc potrzeba przeprowadzenia szczegółowych analiz krajobrazów pasterskich na obszarach górskich, gdzie występuje gospodarka na polanach (sztucznych halach) łącząca elementy działań pasterskich szałaśniczych oraz pastersko-rolniczych, tzw. polaniarskich. Ze względu na zanikający charakter gospodarki polaniarskiej, w szczególności na obszarze Karpat Zachodnich i Wschodnich, istnieje nagląca potrzeba prowadzenia badań w kierunku inwentaryzacji i analizy etnogeograficznej oraz krajobrazowej (systematyzacji w grupie przyrodniczo-kulturowej krajobrazów aktualnych). Wyniki tych badań mogą być istotne zarówno dla planowania działań z zakresu ochrony przyrody, jak i ochrony wiejskich krajobrazów kulturowych związanych z gospodarką górską.

Celem pracy jest próba wskazania na polaniarstwo, jako głównego typu gospodarki górskiej kształtującej krajobrazy beskidzkie, które może stanowić istotny wyróżnik w badaniach nad typologią krajobrazów wiejskich - pasterskich. Do realizacji celu ważny stał się opis działań gospodarczych na polanach, ze szczególnym wyróżnieniem charakterystycznych elementów jej struktury i funkcji, stanowiących istotne kryteria przy systematyzacji krajobrazów górskich z grupy przyrodniczo-kulturowej.

W opisie działań gospodarczych, dla ich pełniejszego opisu i wyjątkowości, autorzy zwrócili uwagę na krajobraz sensoryczny, już nieistniejący jednakże stanowiący o osobliwości krajobrazów beskidzkich. Dawne śpiewy podczas prac pasterskich i polowych, w szczególności podczas wieczornych biesiad na oddalonych polanach, były formą komunikowania się pasterzy ze sobą. Tak zwane łukanie rozchodziło się echem po szczytach i dolinach regionu, wzbogacając jego wartości estetyczne i kulturowe.

Podjęte badania są częścią szerszego problemu badawczego przyjętego przez autorów, jakim jest opracowanie etnogeograficznego modelu gospodarki polaniarskiej dla pasm beskidzkich Karpat Zewnętrznych (Bojko 2009a; 2009b; Bojko/Łach 2016; Łach 2010; 2016).

Materiał do badań pozyskano podczas badań terenowych polegających na inwentaryzacji opisowej, fotograficznej, dokładnym opisie polan wraz z występującą zabudową gospodarczą. Materiał źródłowy - opisowy pozyskano podczas wtórnych (korygujących) wywiadów środowiskowych z nielicznymi już użytkownikami polan. Do realizacji celów pracy wykorzystano metodę wyróżników i wyznaczników krajobrazu (Myczkowski 2015, Myga-Piątek/Chmielewski/Solon 2015), na które składa się kultura i tradycja miejsca, jako podstawy tożsamości, oraz przestrzeń materialna. Przestrzeń ta badana jest zarówno pod kątem uwarunkowań kulturowo i cywilizacyjnych (czynnik etnograficzny), jak i gospodarczych (czynniki ruralistyczne osadnictwa sezonowego wraz ze strukturą użytkowania gruntów oraz czynniki architektoniczno-krajobrazowe). Za istotne wyróżniki do badań przyję- 
to: formy organizacji prac na polanach, ich wpływu na zróżnicowanie struktury użytkowania oraz struktury i funkcji zespołu zabudowy polaniarskiego podczas letnich, sezonowych prac.

\section{Rola etnosu wołoskiego jako kryterium genezy w procesie systematyzacji krajobrazów Karpat Zachodnich}

Pasterskie tradycje w całych Karpatach związane są z ludnością wołoską - koczowniczym ludem przybyłym z Bałkanów, o niewyjaśnionym, wciąż problematycznym pochodzeniu i składzie etnicznym (Czamańska 2015). W XIII stuleciu odnotowano jej obecność na Bałkanach, skąd wyruszyła ku łukowi Karpat w trzech kolejnych falach migracyjnych. Głównym czynnikiem, który najprawdopodobniej stymulował ekspansję Wołochów na północ i zachód, był przyrost naturalny społeczności pasterskich oraz związana z tym konieczność zwiększania stad i zajmowania nowych terenów wypasowych (Dobrowolski 1938; 1970; Jawor 2015). Pierwsza fala wołoska, bardzo nieliczna, dotarła do łuku Karpat Wschodnich prawdopodobnie pod koniec XIII i na początku XIV wieku (Tyvodar 1994; Bojko 2015). Druga, liczniejsza przybyła na obszar Karpat Zachodnich na przełomie XV i XVI wieku, a trzecia w XVII stuleciu (Dobrowolski 1970; Plit 2004; Sobala 2016).

Wołosi to określenie szeregu archaicznych grup etnicznych, które funkcjonowały w ramach klanowej struktury plemiennej, nigdy niewykształcającej własnej tożsamości narodowej (Czamańska 2015). Wołosi byli wędrownym ludem pasterskim, który na skutek ciągłego przemieszczania się uległ rozproszeniu. W trakcie wędrówek stopniowo asymilowali się z lokalnym społeczeństwem, zatracając cechy wspólnoty plemiennej, przejmując nowe wzorce (Dobrowolski 1970; Moszyński 1967; 1996). Mimo tych przemian, jako wspólnota pierwotnie pasterska, odznaczali się pewną hermetycznością oraz przywiązaniem do własnej tradycji. Dzięki temu relikty owej pierwotnej wspólnoty są do dziś widoczne wśród licznych współczesnych grup zamieszkujących Karpaty. W region ten Wołosi wnieśli istotny wkład w formowanie wspólnoty kulturowej grup etnicznych: górali polskich (od górali śląskich na zachodzie po górali sądeckich na wschodzie), ruskich (Łemków, Bojków i Hucułów), Wołochów morawskich i słowackich, przekazując im górski system gospodarki pasterskiej, wzorce kulturowe i słownictwo (Gudowski 2001; Musiał 2010; Jawor 2015; Bojko 2015). Wejście „etnicznych” Wołochów na nowe terytoria prowadziło do nieuchronnej konfrontacji z innym żywiołem etnicznym, a kończyło się rozciągniętą na czas życia kilku pokoleń całkowitą asymilacją przybyszów (Dobrowolski 1938; Łach/Musiał 2015). Pod koniec XVI wieku na obszarze Karpat Zachodnich dokonała się zmiana $w$ typie gospodarowania $\mathrm{z}$ typu transhumancji na typ określany jako letni wypas górski, który przyczynił się do zatrzymania się 
wędrówki osadników wołoskich (Hołub-Pacewiczowa 1930; Kopczyńska-Jaworska 1961a; 1962; Novak i in 2013; Sobala, 2014). Osiedlanie się pasterzy wołoskich miało znaczący wpływ na krajobraz. W wyniku karczowania lasu powstawały polany śródleśne z sezonową zabudową gospodarczą oraz mieszkalno-gospodarczą, a także ścieżki, dukty, ujęcia wody. Nowo powstały krajobraz z dużym udziałem polan śródleśnych wpłynął na różnorodność ekosystemów, dzięki możliwości bytowania nowych gatunków roślin i zwierząt, a materialne dziedzictwo spadkobierców wołoskich na trwałe zmieniło krajobraz Puszczy Karpackiej.

\section{Formy gospodarki górskiej na obszarze Beskidu Małego jako ważny wyróżnik w systematyzacji krajobrazowej}

Na obszarze Karpat główną formą gospodarowania górskiego było pasterstwo wędrowne (szałaśnictwo) oraz działania pastersko-rolne zwane polaniarskimi.

Pasterstwo wędrowne - szałaśnictwo - charakteryzuje się przebywaniem ze stadem zwierząt poza ekumeną przez określoną część roku w celu jego mobilnego wypasu na pastwiskach oraz pozyskania od nich i przetworzenia na miejscu mleka (Kopczyńska-Jaworska 1961b; Novak 2013; Antoniewicz 1959-1970). Natomiast gospodarka polaniarska charakteryzuje się bardziej zróżnicowaną strukturą niż szałaśnictwo. Podstawą eksploatacji jest indywidualna, stacjonarna, a nie społeczna (grupowa) własność polan, na których główną funkcją była produkcja paszy (siana), w mniejszym stopniu płodów rolnych (ziemniaków, żyta czy buraków) (Dorywalska 1974; Zawiejska 1986; Łach/Musiał 2015; Bojko 2009a; 2009b). W obrębie poszczególnej parceli większa powierzchnia użytkowana była jako łąka kośna lub pastwisko, mniejsza pod uprawę w zależności od decyzji właściciela. W strukturze organizacji działań wypasowych występowały dwie formy gospodarowania, wypas dzienny oraz wypas sezonowy chrakteryzujący się kilkutygodniowym (od maja-czerwca do września) pobytem na polanie lub polanach tego samego właściciela (ryc. 1).

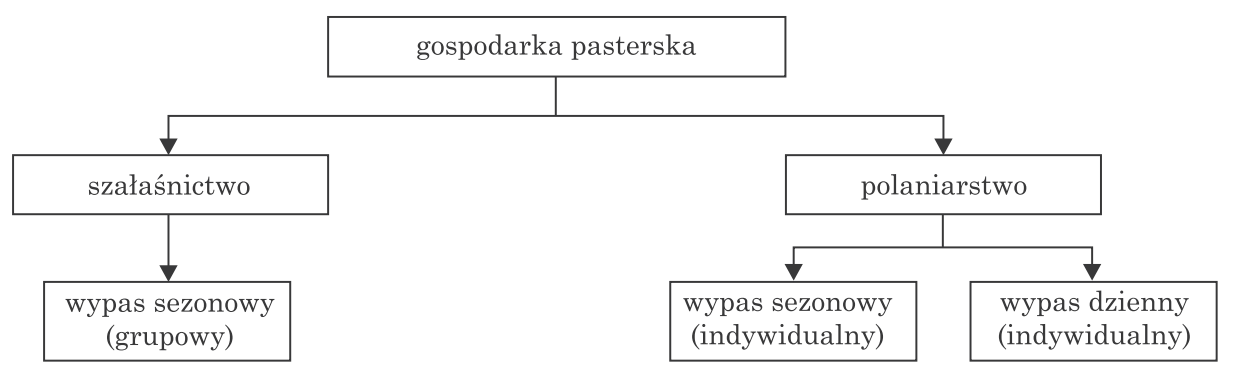

Ryc. 1. Społeczna forma gospodarki pasterskiej na obszarze Karpat Polskich pod koniec XX wieku 
Wypas dzienny charakteryzował się wyprowadzaniem bydła i owiec na polany w ciągu dnia, a następnie jego sprowadzenie na nocleg do obory, natomiast wypas sezonowy był bliższy tradycji szałaśniczej (nocowania w szałasach). W przypadku pozostania na polanie funkcję opieki nad niewielką liczbą zwierząt przejmowała jedna dorosła osoba (pasterz-owczarz), mająca kilku pomocników pochodzących przeważnie $\mathrm{z}$ rodziny. $\mathrm{W}$ ochronie dobytku pasterzom towarzyszył pies pasterski. Do koszenia trawy oraz do prac polowych dochodziły osoby dorosłe - krewni z rodziny właściciela polany oraz sąsiedzi. W zależności od tego, jakie funkcje gospodarcze polany pełniły w określonym roku, można wyznaczyć dwa typy użytkowania polan: typ hodowlano-sianokośny oraz hodowlano-sianokośno-uprawny (Łach i in. 2015). Typ pierwszy obejmował wypas połączony z hodowlą oraz z jednoczesną produkcją surowca roślinnego, jakim jest siano. Obok pasienia i dozoru stada główną powinnością pasterzy było dwukrotne w ciągu dnia dojenie owiec. Dopiero późnym latem i jesienią, kiedy dzień był już bardzo krótki i trawa mało kaloryczna, owce dojono tylko raz w ciągu dnia. Mleko z udoju znoszono do wsi w celu produkcji serów typu bryndza, bundz, oscypek, gołka czy płynnej żętycy.

Ze względu na formę prowadzenia zajęć pastersko-rolniczych na polanach śródleśnych raz, rzadko dwa razy do roku koszono twardą trawę zwaną szczotka lub skuciorą. Pozyskanie siana podczas drugiego sianokosu było możliwe, gdy właściciele nielegalnie wypasali trzodę w lasach wcześnie rano lub wieczorem, „kiedy leśniczy nie gospodarzył w lesie”. Gotową do koszenia trawę kosiło kosami do dziesięciu chłopów, zwykle na rosie lub po deszczu. Na śniadanie, obiad i podwieczorek gospodarze przynosili dobre jedzenie i gorzałkę, bo „bez niej kosa nie chciała kosić". Kobiety rozbijały grabiami pokos, wesoło gwarząc lub śpiewając (łukając) ulubione piosenki i przyśpiewki. Skoszoną trawę, która jeszcze nie miała postaci siana, a którą należało chronić przed deszczem, kobiety i mężczyźni zgrabiali na kopce, tzw. klabnioki ${ }^{1}$, lub przy pomocy ostrewki formowali snopki (kopy) ${ }^{2}$. Gdy uzyskano siano o odpowiedniej wilgotności, jego część chowano do szop na polanach, natomiast pozostałe zwożono do wsi. Siano zwożono wozem drabiniastym, dla zabezpieczenia którego z tyłu wiązano dwa lub trzy nieokrzesane drzewa - świerki lub buki. Była to tzw. zwłać, która zabezpieczała furę przed wywróceniem. Wraz z folgą (hamulcem ręcznym) i łańcuchami spowalniała wóz zjeżdżający z gór (Stachura 1998). W zimie do zwózki siana wykorzystywano sanie.

Drugi typ użytkowania obejmował zadania wymienione w typie pierwszym uzupełnione o uprawę owsa, żyta, ziemniaków i buraków. W strukturze użytkowej polany około $1 / 3$ powierzchni przeznaczano pod uprawę, która w zależności od potrzeb była prowadzona przez 2-3 lata, po czym pole zarzucano pod łąkę, którą wzbogacano nawozem pochodzącym ze zwierząt na wypasie przez kolejne 2-3 lata.

\footnotetext{
${ }^{1}$ klabniok - sterta siana ułożona na łące bez ostrewki

${ }^{2}$ snopek - streta siana ułożona na ostrewce, czyli pniu drzewa świerkowego z bocznymi odnogami
} 
Poletka uprawne grodzono prymitywnym drewnianym lub kamiennym płotem $(k r u d a)$ chroniącym pole przed zwierzętami gospodarskimi oraz leśnymi.

$\mathrm{W}$ gospodarce polaniarskiej zasadnicze znaczenie miał wypas bydła, owiec na skoszonych łąkach pozwalający na nawożenie gleb. Wczesną wiosną, kiedy zwierzęta wygryzły trawę wokół domostw, wyprowadzano je na górskie łąki oddalone od gospodarstw o około 1-2 godziny drogi, na których pojawiała się świeża trawa. Uciążliwość codziennego prowadzenia zwierząt na wypas uwarunkowana stromymi zboczami, kamienistymi drogami spowodowała, iż pasterze wyprowadzali zwierzęta na okres od miesiąca do dwóch-trzech miesięcy, co pozwalało na odrastanie traw na łąkach położonych w pobliżu wsi. Na polanach pasterze zakładali tzw. zespół zabudowy polaniarskiej, który tworzyły: szopa typu fenil, pełniąca funkcję magazynu na siano i sprzęt rolniczy, szopa pastwiskowo-inwentarska, drewniany koszor, kamienny murek zwany kruda, prymitywny szałas oraz kuchenka i bardzo rzadko - drewniana bacówka lub kamienna koliba (letniok).

Zespół zabudowy polaniarskiej, wraz z prowadzonymi działaniami gospodarskimi na polanie śródleśnej pozwolił, na wyróżnienie dwóch typów strukturalno-funkcjonalnych. Typ I o strukturze pastwiskowo-łąkowej (po szałaśnictwie druga forma użytkowania ziemi i hodowli górskiej) oraz typ II - bardziej złożony o strukturze pastwiskowo-łąkowo-uprawnej związany z łączeniem kultury pasterskiej z kulturą rolną. Te dwa typy tworzyły specyficzny układ architektoniczno-krajobrazowy, którego centralnym elementem była polana śródleśna otoczona drzewami bukowymi i świerkowymi (ryc. 2).

Polanę, w zależności od decyzji właściciela, dzielono na strefę łąki kośnej, koszarowania, wypasu oraz uprawy roli. Zespół zabudowy polaniarskiej lokowano przeważnie na skraju polany. Liczba budynków zależna była od położenia polany od wsi. Na polanach położonych blisko wsi do 1 godziny marszu stawiano tylko
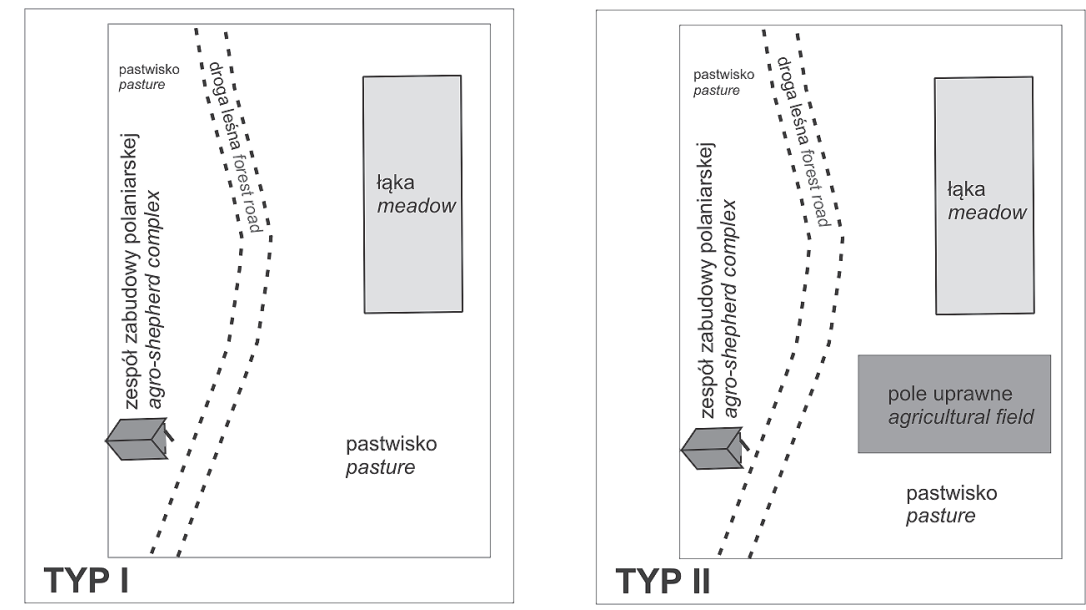

Ryc. 2. Schemat zmian struktury użytkowania polany 

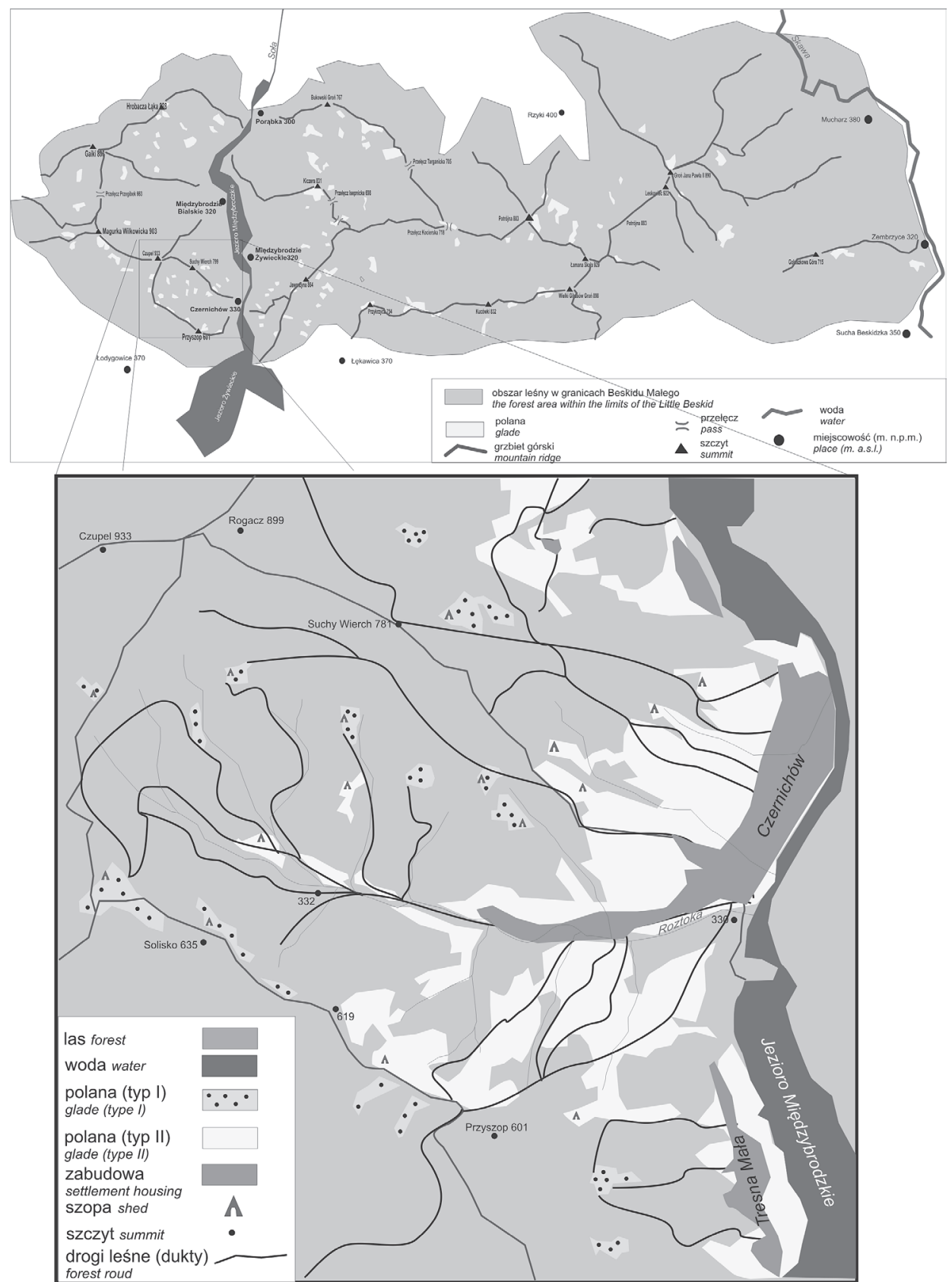

Ryc. 3. Krajobraz polaniarski o układzie mozaikowym w zachodniej części Beskidu Małego w grupie Magurki Wilkowickiej 
szopę, kosor, szałas, natomiast na odleglejszych polanach, gdzie pasterze pozostawali na noc przez kilka tygodni, dodatkowo budowano kolibo-bacówkę lub kamienną kolibę (letniok). Ważnymi elementami w strukturze polany były drogi i ścieżki pozwalające dotrzeć na polanę ze zwierzętami i sprzętem, a także wywieść surowce i plony zebrane podczas letnich działań gospodarskich.

Przestrzeń materialna, którą tworzą powyższe elementy użytkowania polan wraz $\mathrm{z}$ siecią dróg gospodarczych, na leśnym tle tworzy chaotyczny układ przestrzenny. Z kryterium analizy formy krajobrazowej możemy określić za T. Chmielewskim i A. Kułach (2014) jako mozaikowy. Krajobraz na przykładzie regionu Beskidu Małego charakteryzuje się zróżnicowanym pokryciem terenu stanowiącym tło krajobrazowe. Na tło składają się lasy mieszane bukowo-świerkowe (regla dolnego), polany pastersko-rolne (śródleśne) użytkowane jako łąki sianokośne, pastwiska, odłogi, dawniej jako grunty orne. Na mozaikowość wpływają jeszcze grunty rolnicze pomiędzy strefą osadniczą a strefą lasu, użytkowane jako łąki sianokośne, pastwiska, grunty orne drogi gospodarcze (ryc. 3).

Poszczególne pola (polany) są różnej wielkości nieprzekraczającej 2 ha o chaotycznym ułożeniu przestrzennym. Również kształt polan jest niejednakowy (głównie wieloboczny) warunkowany topografią. Pomimo dominującego udziału powierzchni leśnych w tym typie krajobrazu wyróżniającym elementem są polany pastersko-rolnicze.

\section{Zabudowa polaniarska Beskidu Małego jako wyróżnik funkcji krajobrazów Karpat Zachodnich}

Obecnie w krajobrazie Beskidu Małego z zespołów polaniarskich pozostały w formie ruin kamienne i drewniane szopy oraz kamienne koliby tworzące niegdyś stacjonarną zabudowę. Wyróżniającą zabudową polaniarską regionu Beskidu Małego jest jednoizbowa budowla o funkcjach stacjonarnego magazynu nazywana lokalnie szopą lub budą (Łach 2016). Szopa posiada dach dwuspadowy o konstrukcji krokwiowo-jętkowej kryty gontem, darnicą lub blachą. Dach osadzony jest na ścianach z bali, desek oraz rzadko spotykanych ścianach z kamienia. Wejście do szopy najczęściej wąskofrontowe zamykane jest drewnianymi drzwiami na kutych zawiasach z metalową zasuwą lub metalowym skoblem. We wnętrzu znajdują się: klepisko, pniak służący jako stolik, a na ścianach - haki wykonane z gwoździ, sufit tworzą 3-4 belki służące do przechowywania siana na strychu. Cecha charakterystyczna budowli to brak okien oraz dymnik, co świadczy o głównej funkcji użytkowania (Łach 2010; Łach/Musiał 2015). Budowle regionu mają zbliżoną kubaturę $12 \mathrm{~m}^{2}$.

Na podstawie analizy konstrukcji oraz wyglądu (architektury) wyróżniono następujące typy zabudowy polaniarskiej w regionie Beskidu Małego (fot. 1): 
1) typ pierwszy (TYP I) to kamienna szopa o fundamentach i ścianach zbudowanych z kamienia ułożonego ciasno jeden na drugim na wysokość 1,5-1,7 m, na których osadzony jest drewniany dach konstrukcji krokwiowo-jętkowej, pokryty gontem, darnicą lub blachą. Grubość kamiennych murów wynosi około $30-40 \mathrm{~cm}$. Obiekt nie ma okien oraz dymnika. Wejście na strych znajduje się po drugiej stronie

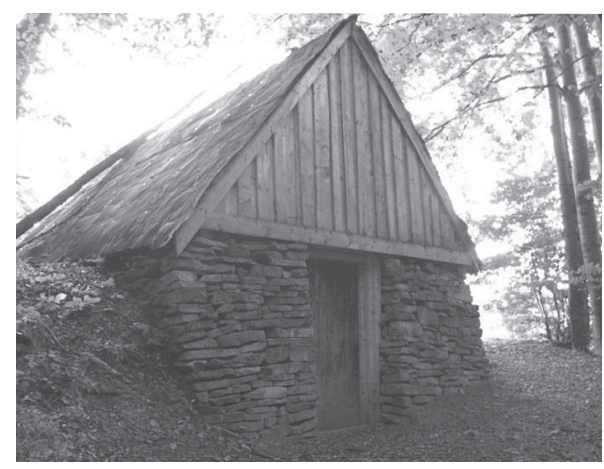

Typ I. Szopa kamienna stone shed

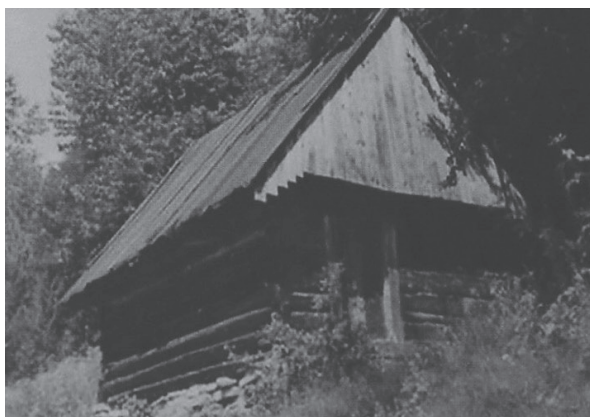

Typ II B. Szopa drewniano-kamienna (wysokozrębowa) wooden-stone shed (high log structure)

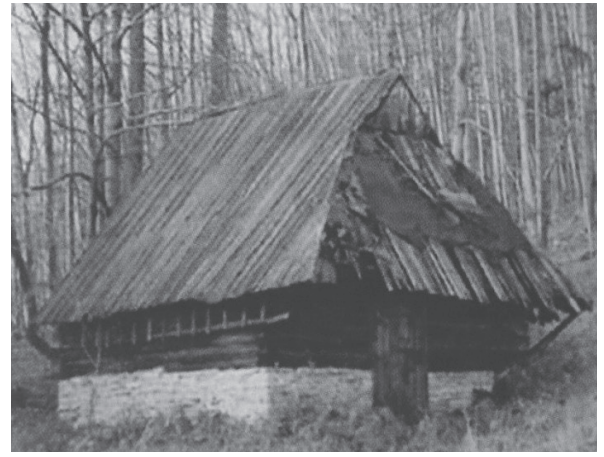

Typ II A. Szopa drewniano-kamienna (niskozrębowa) wooden-stone shed (low log structure)

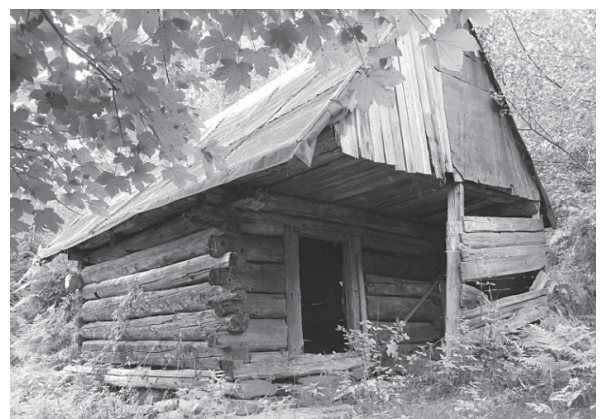

Typ II C. Szopa drewniano-kamienna wooden-stone shed

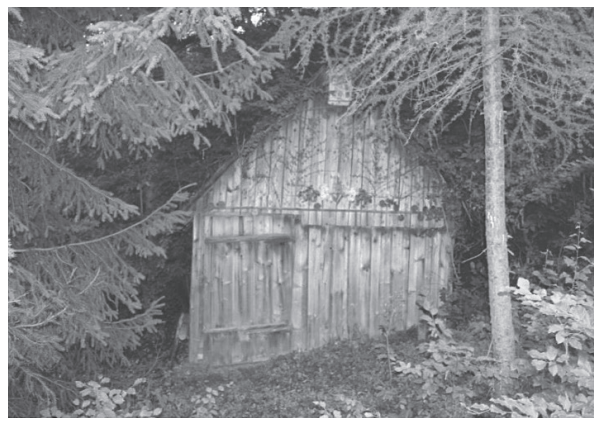

Typ III. Szopa drewniana wooden shed

Fot. 1. Typy konstrukcyjno-architektoniczne zabudowy polaniarskiej regionu Beskidu Małego 
ściany szczytowej, na poziomie gruntu, gdyż obiekt wpuszczany był w skarpę terenową, z którą tworzy trwałą podstawę - fundament jednej z czterech ścian. Ważny jest fakt, iż w konstrukcji tej szopy występuje podtyp wąsko- i szerokofrontowy, a nie jak wcześniej wskazywano (Łach 2010) jedynie wąskofrontowy;

2) typ drugi (TYP II) to szopa drewniano-kamienna o konstrukcji krokwiowo-zrębowej. Charakteryzuje się występowaniem kamiennych fundamentów do wysokości około $0,5 \mathrm{~m}$, na których osadzone są na zrąb drewniane bale, przykryte dachem konstrukcji krokwiowo-jętkowej pokrytym darnicą, gontem lub blachą. W tym typie wyróżnić można dwa podtypy: niskozrębowy do 4 belek zrębowych (TYP II A) i wysokozrębowy, który tworzy 8 belek zrębowych (TYP II B). Podobnie jak w przypadku pierwszego typu są to obiekty jednoizbowe wąskofrontowe, nieposiadające również otworów okiennych oraz dymnika. Szopy mają jednak strych, do którego można dostać się za pomocą drabiny od zewnątrz, od ściany frontowej. W tym typie konstrukcyjnym występuje jeszcze TYP II C, którego wyróżnienie stanowi okap powstały w wyniku wypuszczenia dachu nad wejściem. Powstałe zadaszenie chroniło sprzęt lub zwierzęta podczas złej pogody. Istotnym elementem konstrukcyjnym jest również wejście na strych, które znajduje się wewnątrz szopy;

3) trzeci typ (TYP III) to szopa drewniana o konstrukcji szkieletowej, ściany tworzą deski ułożone pionowo, dach dwuspadowy konstrukcji krokwiowo-jętkowej kryty jest deskami, wejście wąskofrontowe - asymetryczne (inaczej jak w wyżej opisanych typach). W strefie dachu znajduje się strych, na który wejście jest w wewnątrz obiektu. Typ ten występuje wyjątkowo w regionie Beskidu Małego (1 obiekt na 37 zinwentaryzowanych).

Wszystkie szopy były lokowane na polanach na wysokości od 450 do $880 \mathrm{~m}$ n.p.m., głównie o ekspozycji południowej i południowo-zachodniej, w linii drzew otaczających polanę $\mathrm{w}$ celu ochrony przez wiatrem i śniegiem. Ważnym elementem w strukturze polany była droga leśna, przecinająca lub biegnąca w pobliżu, oraz bliskość wody. Miejsce poboru wody znajdowało się od 30 do 150 metrów od polany (Łach/Musiał 2015).

W strukturze zabudowy polaniarskiej Beskidu Małego o typie stacjonarnym istotne znaczenie pełniła kamienna koliba nazywana letniokiem. Stawiana była również na skraju polany w linii drzew otaczających polanę (fot. 2), pełniąc funkcje gospodarczo-mieszkalne podczas letnich prac na polanach. Kamienna konstrukcja ścian przykryta była dachem dwuspadowym konstrukcji krokwiowo-jętkowej. Dach pokryty był darnicą lub gontem. Obiekt miał okno, dymnik lub komin, drzwi szerokofrontowe symetrycznie posadowione. W planie wnętrza można było wyróżnić małą sień. $Z$ niej przechodziło się do izby (izbicy), czyli miejsca, w którym spano, gdzie gotowano posiłki oraz przetwarzano mleko, w nielicznych kolibach znajdowała się jeszcze mała komora (spiżarka). Na podstawie prowadzonych badań można stwierdzić, iż obiekty te były stawiane na skraju polan o ekspozycji południowej na wysokościach od 700 do 880 m n.p.m. 


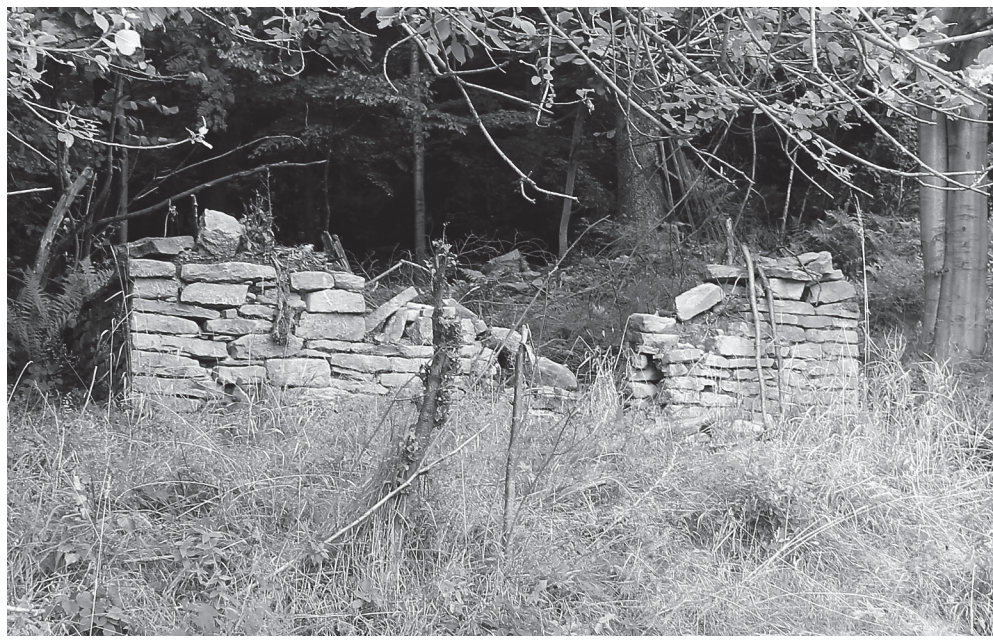

Fot. 2. Kamienna konstrukcja koliby na Palarzówce pod Przykrzycą (fot. J. Łach)

W interpretacji wyróżników polaniarskich zabudowy gospodarczej, obiektywnym wyznacznikiem może być opisana powyżej zabudowa o funkcjach gospodarczych związanych z sezonową działąlnością rolniczo-wypasową (tab. 1).

Tabela 1. Funkcje stałej zabudowy polaniarskiej w paśmie Beskidu Małego

\begin{tabular}{|c|c|c|c|}
\hline \multicolumn{2}{|c|}{ Zadania } & Szopa & Izbica \\
\hline Funkcje magazynowe & siana & TAK & NIE \\
\hline Funkcje magazynowe & narzędzi rolniczych & TAK & TAK \\
\hline Funkcje ochronne & $\begin{array}{c}\text { schronienie dla zwierząt pasterskich - tylko podczas } \\
\text { złych warunków atmosferycznych }\end{array}$ & TAK & NIE \\
\cline { 2 - 4 } & schronienie dla pasterzy & $\begin{array}{c}\text { TAK } \\
\text { sporadycznie }\end{array}$ & TAK \\
\hline Funkcje produkcyjne & przetwarzanie mleka & NIE & TAK \\
\hline $\begin{array}{c}\text { Czas wykorzystania } \\
\text { obiektu }\end{array}$ & $\begin{array}{c}\text { letnie działania pastersko-łąkowe oraz pastersko- } \\
\text { ląkowo-rolne }\end{array}$ & TAK & TAK \\
\hline
\end{tabular}

\section{Podsumowanie}

Krajobrazy Karpat Zachodnich - Beskidów Zachodnich reprezentują mozaikową strukturę przestrzenną powstałą $\mathrm{w}$ wyniku współdziałania procesów naturalnych i antropogenicznych. Te ostatnie są świadomymi modyfikacjami pokrycia i struktury przestrzennej działań gospodarczych w strefie górskiej od XVI wieku. Pojawienie się w regionie Beskidu Małego osadników wołoskich miało wpływ na rozwój społeczny i kulturowy mieszkańców. W procesie asymilacji z lokalną rolniczą kulturą 
przejmowali ich zwyczaje oraz styl życia, jednocześnie przekazując swoje doświadczenia i umiejętności z zakresu wypasu i hodowli oraz umiejętności w budownictwie gospodarczym i mieszkaniowym strefy górskiej. Kultura działań pasterskich strefy górskiej, łącząc się z lokalną kulturą rolną strefy dolinnej, doprowadziła do ewoluowania w kierunku gospodarki pastersko-rolnej (polaniarskiej). Wypas zwierząt, pozyskanie surowca $\mathrm{w}$ postaci siana oraz uprawa miały charakter stacjonarnych działań prowadzonych przez jednego gospodarza, który na czas zajęć sezonowych stawiał tzw. zespół zabudowy polaniarskiej. Główny element tej zabudowy stanowiła szopa jako magazyn siana, pełniący czasami funkcje schronienia dla zwierząt gospodarskich oraz pasterzy. Z analizy typów konstrukcyjno-architektonicznych obiektów na badanym obszarze wynika, że dominowały jednoizbowe budynki o powierzchni $12 \mathrm{~m}^{2}$, konstrukcji drewniano-zrębowej z dachem dwuspadowym krokwiowo-jętkowym, rzadziej natomiast budynki kamiennej konstrukcji, które zostały przez etnografów (Hołub-Pacewiczowa 1930) określone jako wielka osobliwość etnograficzna regionu.

Prowadzone badania nad kryteriami systematyzacji krajobrazowej Karpat Zachodnich (typu średniogórskiego) przy użyciu metody wyróżników i wyznaczników krajobrazu pozwoliło na wytypowanie szczególnie istotnych elementów definiujących strukturę i funkcję tych krajobrazów o funkcjach rolniczych. Zaliczono do nich: 1) formy prowadzonych zajęć na polanach o typie gospodarki pastwiskowo-łąkowej oraz gospodarki pastwiskowo-łąkowo-rolnej, mających wpływ na strukturę przestrzenną polan (Typ I, II); 2) stałą zabudowę o funkcji magazynowej siana i sprzętu rolniczego; 3) brak przetwarzania surowca mlecznego na polanach - znoszenie go do wsi; 4) indywidualny (rodzinny) status działań na polanach.

Wyróżnione cechy gospodarki górskiej na obszarze średnich gór pozwalają na wydzielenie wśród krajobrazów wiejskich, krajobrazów pasterskich z podtypem polaniarskim z grupy krajobrazów przyrodniczo-kulturowych.

\section{Bibliografia}

Antoniewicz, W. (1959-1970), Pasterstwo Tatr Polskich i Podhala. I-VIII. Wrocław/Warszawa/ Kraków.

BoJKo, I. (2009a), Kul'tura zagotovki sena v Slovatskikh i Ukrainskikh Karpatakh (etnoekologicheskiy aspekt). W: Etnos i sreda obitaniya. Sbornik etnoekologicheskikh issledovaniy k 85-letiyu V. I. Kozlova. Moskva, 281-311. [Бойко, I. (2009a), Культура заготовки сена в Словацких и Украинских Карпатах (этноэкологический аспект). Этнос и среда обитания. W: Сборник этноэкологических исследований к 85-летию В. И. Козлова. Москва, 281-311.]

Bojko, I.(2009b), Sporudidlya zberigannya sina ta solomi v Ukraïns'kikh, Pol's'kikh i Slovats'kikh Karpatakh (XX - pochatok XXI st.). W: Fortetsya: zbirnik zapovidnika „Tustan"” na poshanu Mikhayla Rozhka. L'viv/Kamula, 531-550. [Бойко, I. (2009b), Споруди для зберігання сіна та соломи в Українських, Польських і Словацьких Карпатах (XX - початок XXI ст.). W: Фортеця: збірник заповідника „Тустань” на пошану Михайла Рожка. Львів/Камула, 531-550.] 
BoJko, I. (2015), Letnie obory w Karpatach Ukraińskich i Zachodnich: etnoekologiczne podobieństwa w kulturach Ukraińców, Słowaków, Polaków i Czechów. W: Halczak, B./Dudra, S./Drozd, R. et al. (red.), Łemkowie, Bojkowie, Rusini - historia, współczesność, kultura materialna i duchowa. Słupsk/Zielona Góra/Svidnik, 361-376.

Bojko, I./ŁACH J. (2016), Adaptivni strategiï traditsiynogo sezonnogo budivnitstva na polyanakh ta pasovis'kakh u Pivnichnikh Karpata (kinets' XIX - persha polovina XX stolittya). Materiali do kraïns'koï yetnologiï. Vip. 15, 47-56. [Бойко, І./Лях, Я. (2016), Адаптивні стратегії традиційного сезонного будівництва на полянах та пасовиськах у Північних Карпатах (кінець XIX - перша половина XX століття). Матеріали до країнської етнології. Вип. 15, 47-56.]

Chmielewski, T.J./KuŁach A. (2014), Struktura fizjonomiczna krajobrazu. W: Zaja, W./Jodłowski, M. (red.), Struktura środowiska przyrodniczego a fizjonomia krajobrazu. Kraków, 33-53.

Chmielewski, T. J./Myga-PiąTeK, U./Solon J. (2015), Typologia aktualnych krajobrazów Polski. W: Przegląd Geograficzny. 87/3, 377-408.

CZAmańsKa, I. (2015), The Valachs - several research problems. W: Balcanica Posnaniensia. XXII/I, $7-16$.

Dobrowolski, K. (1938), Badania nad ugrupowaniami etnograficznymi w Karpatach Zachodnich. W: Sprawozdania z czynności i posiedzeń Polskiej Akademii Umiejętności. Kraków, 43/5, 183-199.

Dobrowolski, K. (1970), Studia nad kulturą pasterską w Karpatach Północnych, typologia wędrówek pasterskich od XIV do XX wieku. W: Antoniewicz, W. (red.), Pasterstwo Tatr Polskich i Podhala, VIII. Wrocław/Warszawa/Kraków, 98-120.

Dorywalska, E. (1974), Badania nad pasterstwem i gospodarką polaniarską za Żywiecczyźnie. W: Karta Groni. V-VI, 52-56.

Gudowski, J. (2001), Pasterstwo na Huculszczyźnie - gospodarka, kultura, obyczaj. Warszawa.

Holub-Pacewiczowa, Z. (1930), Z badań nad pasterstwem karpackimi alpejskim. W: Wierchy. VIII, 89-121.

JAWOR, G. (2015), Ethnic aspects of settlement in Ius Valachicum in medieval Poland (from the $14^{\text {th }}$ to the beginning of the $16^{\text {th }}$ century). W: Balcanica Posnaniensia. XXII/I, 47-55.

KopCZyŃsKa-JaWORSKA, B. (1961a), Wędrówki pasterskie w Beskidzie Śląskim. W: Etnografia Polska. V, 227-231.

KopCZYŃSKA-JAWORSKA, B. (1961b), Dyskusyjne problemy syntezy badań nad pasterstwem wysokogórskim. W: Etnografia Polska. XXV, 2, 85-96.

KoPCZYŃSKA-JAWORSKA, B. (1962), Szałaśnictwo w Karpatach Polskich w świetle prac zespołowych w roku 1960. W: Etnografia Polska. VI, 321-329.

ŁACH, J. (2010), Kamienne szopy pasterskie jako ginący element krajobrazu Beskidu Małego. W: Wierchy. 76, 244-249.

ŁACH, J. (2016), Rola wyróżników i wyznaczników krajobrazu przyrodniczego i kulturowego w określeniu wyspowego charakteru Beskidu Małego. W: Prace Komisji Krajobrazu Kulturowego. XXXIII, 39-52.

ŁACH, J./Musial, M. (2015), Przeszłość i znaczenie tradycji dla współczesnego oblicza kulturowego góralszczyzny Beskidu Małego - zapis w krajobrazie. Wrocław.

MoszyŃsKi, K. (1967), Kultura ludowa Słowian. Kultura materialna. Warszawa.

MoszYŃsKi, K. (1996), Ludy pasterskie ich kultura materialna oraz podstawowe wiadomości o formach współżycia zbiorowego, o wiedzy, życiu religijnym i sztuce. Cieszyn.

Musiat, M. (2010), Śladami kultury góralskiej w Beskidzie Małym. Andrychów.

Myczkowski, Z. (2015), Kompozycyjne i architektoniczne wyznaczniki tożsamości krajobrazów. W: Problemy Ekologii Krajobrazu. XL, 199-208.

Myga-Piątek, U. (2012), Krajobrazy kulturowe - aspekty ewolucyjne i typologiczne. Katowice.

Myga-Piątek, U./Chmielewski, T. J./Solon J. (2015), Rola cech charakterystycznych wyróżników i wyznaczników krajobrazu w klasyfikacji i audycie krajobrazów aktualnych. W: Problemy Ekologii Krajobrazu. XL, 177-185. 
Novak, J./Podolak, J./Zuskinova, I./Margetin, M. (2013), Po stopach valachov v Karpatoch. Brno. Plit, J. (2004), Przeobrażenia krajobrazów kulturowych Karpat Polskich dawniej i dziś. W: Prace Komisji Krajobrazu Kulturowego. III, 33-43.

Stachura, P. (1998), Międzybrodzie Bialskie - dzieje i obyczaje. Kraków.

Sobala, M. (2014), Krajobrazy pasterskie w Polsce i Europie - wybrane typy, przykłady i formy ochrony. W: Prace Komisji Krajobrazu Kulturowego. 25, 81-98.

Sobala, M. (2016), Landscape effects of conflicts in space management. A historical approach based on the Silesian and Żywiec Beskids (West Carpathians, Poland). W: Environmental \& Socio-economic studies. 4, 51-60.

Tyvodar, M. (1994), Traditional Cattle Breeding in the Ukrainian Carpathian Mountains of the Second Half of XIX-the First Half of XX Century. Uzhhorod.

ZAWIEJSKA, E. (1986), Budownictwo pasterskie w Beskidzie Żywieckim. W: Prace i Materiały Muzeum Archeologicznego i Etnograficznego w Łodzi, Seria Etnograficzna. XXVI, 41-56. 